\title{
Cognitive Enhancement with Rosiglitazone Links the Hippocampal PPAR $\gamma$ and ERK MAPK Signaling Pathways
}

\author{
Larry A. Denner, ${ }^{1,2,5,6,7}$ Jennifer Rodriguez-Rivera, ${ }^{1,3}$ Sigmund J. Haidacher, ${ }^{2}$ Jordan B. Jahrling, ${ }^{1,3}$ J. Russ Carmical, ${ }^{4}$ \\ Caterina M. Hernandez, ${ }^{1,3}$ Yingxin Zhao, ${ }^{2,6,7}$ Rovshan G. Sadygov, ${ }^{4,6,7}$ Jonathan M. Starkey, ${ }^{4}$ Heidi Spratt, ${ }^{4,6,7}$ \\ Bruce A. Luxon, ${ }^{4,6,7}$ Thomas G. Wood, ${ }^{4,6,7}$ and Kelly T. Dineley ${ }^{1,3}$ \\ ${ }^{1}$ Mitchell Center for Neurodegenerative Diseases, ${ }^{2}$ Department of Internal Medicine, Division of Endocrinology, Departments of ${ }^{3}$ Neurology and \\ ${ }^{4}$ Biochemistry and Molecular Biology, ${ }^{5} \mathrm{McCoy}$ Stem Cells and Diabetes Mass Spectrometry Research Laboratory, ${ }^{6}$ Sealy Center for Molecular Medicine, \\ and 7 Institute for Translational Science, University of Texas Medical Branch, Galveston, Texas 77555
}

We previously reported that the peroxisome proliferator-activated receptor $\gamma(\operatorname{PPAR} \gamma)$ agonist rosiglitazone (RSG) improved hippocampus-dependent cognition in the Alzheimer's disease (AD) mouse model, Tg2576. RSG had no effect on wild-type littermate cognitive performance. Since extracellular signal-regulated protein kinase mitogen-activated protein kinase (ERK MAPK) is required for many forms of learning and memory that are affected in AD, and since both PPAR $\gamma$ and ERK MAPK are key mediators of insulin signaling, the current study tested the hypothesis that RSG-mediated cognitive improvement induces a hippocampal PPAR $\gamma$ pattern of gene and protein expression that converges with the ERK MAPK signaling axis in Tg2576 AD mice. In the hippocampal PPAR $\gamma$ transcriptome, we found significant overlap between peroxisome proliferator response element-containing PPAR $\gamma$ target genes and ERK-regulated, cAMP response element-containing target genes. Within the Tg2576 dentate gyrus proteome, RSG induced proteins with structural, energy, biosynthesis and plasticity functions. Several of these proteins are known to be important for cognitive function and are also regulated by ERK MAPK. In addition, we found the RSG-mediated augmentation of PPAR $\gamma$ and ERK2 activity during Tg2576 cognitive enhancement was reversed when hippocampal PPAR $\gamma$ was pharmacologically antagonized, revealing a coordinate relationship between PPAR $\gamma$ transcriptional competency and phosphorylated ERK that is reciprocally affected in response to chronic activation, compared with acute inhibition, of PPAR $\gamma$. We conclude that the hippocampal transcriptome and proteome induced by cognitive enhancement with RSG harnesses a dysregulated ERK MAPK signal transduction pathway to overcome AD-like cognitive deficits in Tg2576 mice. Thus, PPAR $\gamma$ represents a signaling system that is not crucial for normal cognition yet can intercede to restore neural networks compromised by AD.

\section{Introduction}

The nuclear receptor peroxisome proliferator-activated receptor $\gamma(\operatorname{PPAR} \gamma)$ is a well established therapeutic target in type 2 diabetes since its transcriptional activity leads to improved insulin sensitivity in the periphery. Clinical studies suggest that PPAR $\gamma$ agonists such as rosiglitazone (RSG) improve cognitive function in Alzheimer's disease $(\mathrm{AD})$ patients and in several rodent models of the disease (Watson et al., 2005; Pedersen et al., 2006; Risner et al., 2006; Escribano et al., 2009, 2010; Rodriguez-Rivera et al.,

Received May 2, 2012; revised Sept. 19, 2012; accepted Sept. 22, 2012.

Author contributions: L.A.D., J.R.-R., J.R.C., T.W., and K.T.D. designed research;J.R.-R., S.J.H., J.B.J., J.R.C., C.M.H., R.G.S., and J.M.S. performed research; Y.Z. contributed unpublished reagents/analytic tools; L.A.D., J.R.-R., S.J.H., J.B.J., J.R.C., C.M.H., R.G.S., J.M.S., H.S., B.A.L., T.W., and K.T.D. analyzed data; L.A.D. and K.T.D. wrote the paper.

This work was supported by the National Institutes of Health under Grants F31 NS052928 to J.R.-R. and R01AG031859 to K.T.D. and L.A.D. Additional funding was provided by the American Health Assistance Foundation, The Sealy Foundation for Biomedical Research, and a kind gift from J. and W. Mohn to K.T.D.; by the Emmett and Miriam McCoy Foundation to L.A.D.; and by the Cullen Trust for Health Care to the Mitchell Center. Behavioral testing was performed in The University of Texas Medical Branch Rodent In Vivo Assessment Core. Expert technical assistance was provided by Wei Song and Dr. Narayana Komaravelli.

The authors declare no competing financial interests.

Correspondence should be addressed to Dr. Kelly T. Dineley, 301 University Boulevard, Galveston TX 77555-0616. E-mail: ktdinele@utmb.edu.

DOI:10.1523/JNEUROSCI.2153-12.2012

Copyright $\odot 2012$ the authors $\quad 0270-6474 / 12 / 3216725-11 \$ 15.00 / 0$
2011). However, the mechanism by which PPAR $\gamma$ agonists achieve these CNS effects is unclear.

Some mechanistic insight is provided by recent work demonstrating reciprocal PPAR $\gamma$ and extracellular signal-regulated protein kinase mitogen-activated protein kinase (ERK MAPK) activity in several neurological disorders and cancer suggesting a potential action for PPAR $\gamma$ in amelioration of memory deficits in AD (Camp and Tafuri, 1997; Kim et al., 2003; Papageorgiou et al., 2007; Schroeter et al., 2007; Rosa et al., 2008; Zhang et al., 2011). In support of this, chronic elevated $\beta$-amyloid $(\mathrm{A} \beta$ ) leads to dysregulation of hippocampal ERK MAPK in vitro and in vivo (Dineley et al., 2001a; Bell et al., 2004; Swatton et al., 2004), while $\operatorname{PPAR} \gamma$ agonism ameliorates cognitive deficits in vivo and can prevent $\mathrm{A} \beta$-induced deficits in hippocampal plasticity in vitro (Costello et al., 2005; Rodriguez-Rivera et al., 2011). Likewise, both ERK and PPAR $\gamma$ are dysregulated in AD brain and certain $\operatorname{PPAR} \gamma$ polymorphisms are associated with increased risk for the disease (Kitamura et al., 1999; Scacchi et al., 2007).

To investigate the molecular mechanism underlying PPAR $\gamma$ agonism with RSG on AD-like cognitive function, we used an extensively characterized AD mouse model, Tg2576, that expresses a transgene encoding the human amyloid precursor protein containing a mutation that causes $\mathrm{AD}$ in humans (Hsiao et al., 1996). Importantly, Tg2576 mice exhibit age-dependent cog- 
nitive decline as measured in several behavioral paradigms but most notably in those requiring proper hippocampal ERK MAPK function that are also impaired in humans with $\mathrm{AD}$ (Atkins et al., 1998; Dineley et al., 2001b; Dineley et al., 2001a,b, 2002; Hamann et al., 2002; Hoefer et al., 2008).

Therefore, the current study tested whether regulation of hippocampal PPAR $\gamma$ coincided with ERK MAPK signaling following RSG-mediated cognitive improvement. In the hippocampal PPAR $\gamma$ transcriptome of the Tg2576 AD animal model, we found significant overlap between peroxisome proliferator response element (PPRE)-containing PPAR $\gamma$ target genes and cAMP response element (CRE)-containing ERK MAPK [CAMP response element-binding protein (CREB)] target genes. Using quantitative mass spectrometry and bioinformatics on the dentate gyrus, we identified many proteins related to synaptic plasticity and memory formation that were induced concomitant with RSG-mediated cognitive rescue and activation of PPAR $\gamma$ and ERK2, actions reversed when hippocampal PPAR $\gamma$ was pharmacologically antagonized to reverse RSG-mediated cognitive improvement. We conclude that the hippocampal transcriptome and proteome induced by cognitive enhancement with RSG harnesses a dysregulated ERK MAPK signal transduction pathway to overcome AD-like cognitive deficits in Tg2576 mice. Thus, PPAR $\gamma$ represents a signaling system that is not crucial for normal cognition yet can intercede to restore neural networks compromised by $\mathrm{AD}$.

\section{Materials and Methods}

Animals. Animals were bred in The University of Texas Medical Branch animal care facility by mating heterozygous Tg2576 males with C57BL6/ SJL (F1) females (Jackson Laboratory). The University of Texas Medical Branch operates in compliance with the United States Department of Agriculture Animal Welfare Act, the Guide for the Care and Use of Laboratory Animals, and Institutional Animal Care and Use Committeeapproved protocols.

Mice were housed, $n \leq 5$ per cage, with food and water ad libitum. All animal manipulations were conducted during the lights-on phase $(0700-1900$ h). Male and female 8 months old (8MO) Tg2576 and wildtype (WT) littermates were fed control or $30 \mathrm{mg} / \mathrm{kg}$ RSG diet (Bio-Serv) for $30 \mathrm{~d}$, as previously described (Rodriguez-Rivera et al., 2011). Animals were killed by decapitation and the brain was rapidly removed from the skull for hippocampus dissection.

Intracerebroventricular injection. Using a modified free-hand method (Clark et al., 1968), mice were anesthetized (isoflurane, 1-4\%) and, with aseptic technique, the skull was exposed with a small incision along the midline. Hemostatic forceps held the needle $1 \mathrm{~mm}$ anterior and $1 \mathrm{~mm}$ lateral of the bregma. GW9662 (32.5 pmol, $3 \mu \mathrm{l})$ or vehicle (dimethyl sulfoxide) were delivered by an electronic programmable microinfuser (Harvard Apparatus) at $3 \mu \mathrm{l} / \mathrm{min}$ and the needle left in place for $1 \mathrm{~min}$ postinjection. This dose was based on previous reports of intracerebroventricular (ICV) injection of GW9662 to antagonize PPAR $\gamma$ function in the CNS (Maeda et al., 2007; Zhang et al., 2008).

Fear conditioning. Two-pair fear conditioning (FC) training and FC hippocampus-dependent contextual testing was performed on awake and alert subjects $4 \mathrm{~h}$ after ICV injection. Eight to 12 mice per group (male and female) were trained in the FC chamber following our standard FC protocol, as described previously (Dineley et al., 2002). Twentyfour hours later, mice were returned to the training chamber for testing in the hippocampus-dependent contextual FC paradigm. Cued FC was not included in this study since Tg2576 are not deficient in the hippocampus-independent cued FC task and RSG treatment has no effect on WT or Tg2576 performance in this task (Dineley et al., 2002; Rodriguez-Rivera et al., 2011). Following testing, mice were decapitated and the hippocampus and cortex were immediately dissected, frozen on dry ice, and stored at $-80^{\circ} \mathrm{C}$.

Shock threshold. Approximately 9 animals per group were subjected to shock threshold test to assess shock sensitivity, as described previously
(Dineley et al., 2002). Briefly, a sequence of single foot shocks was delivered to animals placed on the same electrified grid used for fear conditioning. Initially, a $0.1 \mathrm{mV}$ shock was delivered for $1 \mathrm{~s}$, and the animals' behavior was evaluated for flinching, jumping, and vocalization. At $30 \mathrm{~s}$ intervals the shock intensity was increase by $0.1 \mathrm{mV}$ up to $0.7 \mathrm{mV}$ and then returned to $0 \mathrm{mV}$ in $0.1 \mathrm{mV}$ increments at $30 \mathrm{~s}$ intervals. Threshold to vocalization, flinching, and then jumping was quantified for each animal by averaging the shock intensity at which each animal manifested a behavioral response to the foot shock.

Nuclear extraction. Following the manufacturer's instructions (Active Motif), extracts were prepared from the hippocampi of individual animals. Immunoblot analyses for subcellular fraction markers determined $>95 \%$ purity (data not shown).

DNA binding assays. Eight micrograms of nuclear extract was assayed for PPAR $\gamma$ binding to the PPRE with TransAM ELISA kit (Active Motif) according to the manufacturer's instructions. Data are reported as mean \pm SEM normalized to WT signal.

Antibodies. Phospho-Ser84 PPAR $\gamma$ (1:500; MAB3632) and PPAR $\gamma(1$ : 200; 07-466) were obtained from Millipore. ERK (1:1000; 9102) and phospho-Thr202/Tyr204 ERK (1:1000; 9101) were obtained from Cell Signaling Technology. $\beta$-Actin (1:5000; A5441) was obtained from Sigma. Lamin A/C (1:100; SC-20681) was obtained from Santa Cruz Biotechnology. HRP-conjugated anti-mouse IgG (1:50,000; NA931V) and anti-rabbit IgG (1:100,000; NA934V) were obtained from GE Healthcare.

Quantitative immunoblot. Using our previously described method (Dineley et al., 2001b), 10 - $40 \mu \mathrm{g}$ (DC Protein Assay, Bio-Rad) of nuclear or cytosolic hippocampal extract from individual animals was resolved by SDS-PAGE, transferred to PVDF membrane (Immobilon, Millipore), then probed with the appropriate primary and secondary antibodies. Protein bands were detected by chemiluminescence (Advance ECL, GE Healthcare) and film exposures in the linear range for the antigenantibody combination were developed with a Kodak imager (Kodak). Band densities were measured with Image $(\mathrm{NIH})$ and normalized to control level. Normalized control values were determined for each immunoblot by averaging control values, dividing each control and test sample density by the average of the control set, and then determining the average and SEM for control and test samples for $n=6-10$ animals/ group. All blots were sequentially probed for PPAR $\gamma$ phosphorylated on Ser84, PPAR $\gamma$, ERK phosphorylated on Thr202/Tyr204, ERK, then lamin or actin for normalization.

$R N A$ extraction and PPAR $\gamma 1$ and PPAR $\gamma 2$ reverse transcriptase-PCR. Hippocampi from WT mice were dissected out and stored in RNAlater RNA protection solution (Ambion, catalog \#AM7024) for further analysis. Total RNA was isolated from the tissue using RNAqueous-Micro Kit (Ambion) following the manufacturer's instructions. RNA sample quality and quantity were analyzed using Agilent 2100 Bioanalyzer and Nanodrop ND1000, respectively. One microgram of total RNA was synthesized into cDNA using Transcriptor High Fidelity cDNA Synthesis Kit (Roche Applied Science) according to the manufacturer's instructions and subjected to PCR with primers (Sigma-Genosys) specific for PPAR $\gamma 1$ and PPAR $\gamma 2$ transcripts. PCR ( 25 cycles) was performed (PerkinElmer PE2400) under the following conditions: $94^{\circ} \mathrm{C}, 30 \mathrm{~s} ; 58^{\circ} \mathrm{C}$, $20 \mathrm{~s} ; 72^{\circ} \mathrm{C}, 20 \mathrm{~s}$. PCR products were analyzed in $2 \%$ agarose gels in Tris-acetate-EDTA buffer with base pair marker.

Quantitative PCR. Individual hippocampi were collected from 4 animals (male and female) of each group (WT untreated, untreated Tg2576, RSG-treated Tg2576) and suspended in 20-fold excess (w/v) TRIzol (Invitrogen). The tissue was homogenized in a $1 \mathrm{ml}$ Dounce homogenizer on ice and RNA extracted according to the manufacturer's instructions. Quality control assessment of total RNA was performed on an Agilent 2100 Bioanalyzer (Agilent Technologies) as well as $A_{260} / A_{280}$ and $A_{260} /$ $A_{230} \mathrm{~nm}$ ratio analyses using NanoDrop technology (Thermo Scientific). cDNA was synthesized from $5 \mu \mathrm{g}$ of hippocampal mRNA using Superscript III (Invitrogen) according to the manufacturer's instructions. Individual animal mRNA was quantified for a custom array of predominantly PPRE-containing PPAR $\gamma$ genes on $1 \mu \mathrm{l}$ of cDNA using a Roche LightCycler 480 and LightCycler 480 SYBR Green I Master reagent (Roche Applied Science) in the University of Texas Medical Branch Mo- 
Table 1. PPREs and CREs in RSG-Regulated Hippocampal Genes in Tg2576

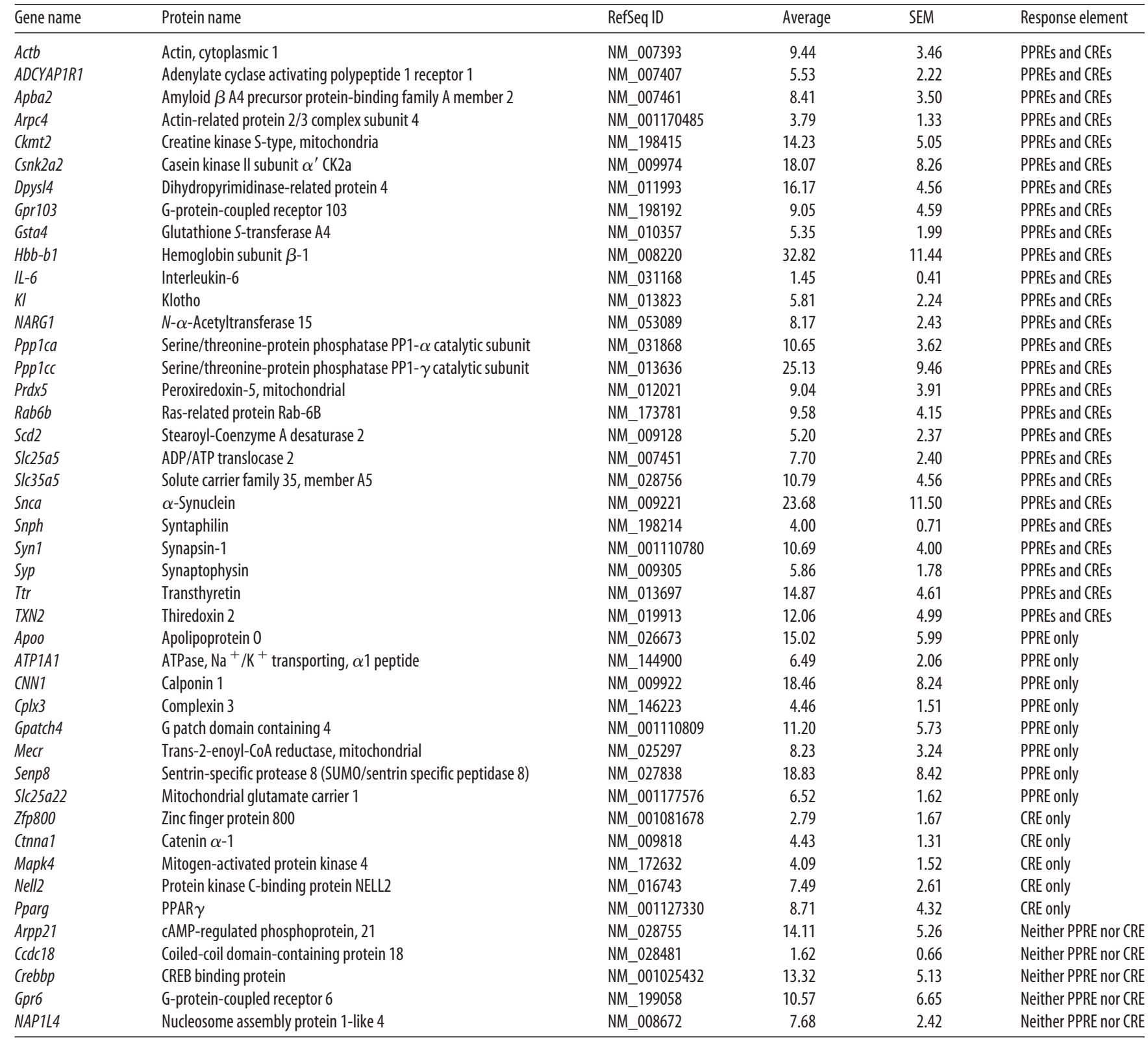

Fold-change values are given for RSG-regulated genes in Tg2576 hippocampus. Gene and protein name with NCBI reference sequence identification numbers are listed with fold-change determined using quantitative PCR. Also denoted is presence of PPRE and/or CRE in the target gene promoters.

lecular Genomics Core Facility. All oligos (Table 1) were purchased from Integrated DNA Technologies $\Delta C_{\mathrm{T}}$ values were calculated by subtracting the average $C_{\mathrm{T}}$ of three housekeeping genes (GAPDH, Rpl19, and Bpol) from each gene of interest and the $\Delta \Delta C_{\mathrm{T}}$ method (Applied Biosystems) was used to calculate fold-change values between treatment groups. $-\Delta C_{\mathrm{T}}$ values are shown (Figs. $\left.1 B, 2 D\right)$ to indicate increased number of mRNA transcripts.

Quantitative mass spectrometry. Stable isotope labeling was used to quantify differential protein expression as previously described (Sadygov et al., 2010; Starkey et al., 2010). Briefly, the dentate gyrus from 10 mice each of Tg2576 fed control or RSG diet were homogenized in TRIzol and the protein pellet resuspended in guanidine. Following reduction and alkylation, proteins were digested with trypsin and peptides desalted with SepPack C18 cartridges. Dried peptides were then treated with immobilized trypsin (Applied Biosystems) in normal water $\left(\mathrm{H}_{2}{ }^{16} \mathrm{O}\right)$ or heavy water $\left(\mathrm{H}_{2}{ }^{18} \mathrm{O}\right)$ for trypsin-mediated exchange of oxygen atoms from water onto the $\mathrm{C}$ terminus of peptides. Desalted peptides were then pooled to prepare a mixture of ${ }^{16} \mathrm{O}$-labeled peptides from control-fed mice and ${ }^{18} \mathrm{O}$-labeled peptides from RSG-fed mice. To reduce the sample complexity and increase the depth of analysis into the proteome, the peptide mixture was resolved into 60 fractions using strong cation exchange chromatography.

Two-dimensional liquid chromatography-tandem mass spectrometry. Each SCX fraction was injected onto a C18 peptide trap (Agilent), desalted, and eluted peptides separated on a reversed phase nano-HPLC column with a linear gradient over $120 \mathrm{~min}$ at $200 \mathrm{nl} / \mathrm{min}$. Liquid chromatography-tandem mass spectrometry (LC-MS/MS) experiments were performed with a LTQ linear ion trap mass spectrometer (ThermoFinnigan) equipped with a nanospray source. The mass spectrometer was coupled online to a ProteomX nano-HPLC system (ThermoFinnigan). The mass spectrometer was operated in the data-dependent tripleplay mode. In this mode, the three most intense ions in each MS survey scan were automatically selected for moderate resolution zoom scans which were followed by MS/MS. Each of the peptide mixtures was repetitively analyzed by nano-HPLC-MS/MS three times. The acquired MS/MS spectra were searched with SEQUEST algorithm performed on the Bioworks 3.2 platform (ThermoFinnigan) using conservative filtering criteria of $S p \geq 300, \Delta C n \geq 0.12$, and Xcorr of 1.9, 2.0 and 3.0 for data from a singly, doubly or triply charged precursor ions, respectively. 
A

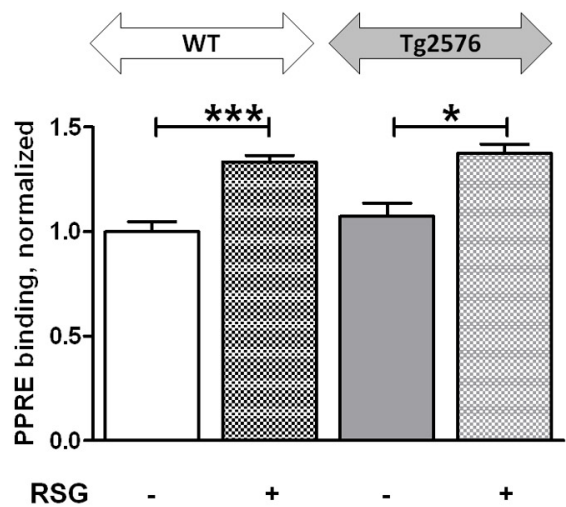

C

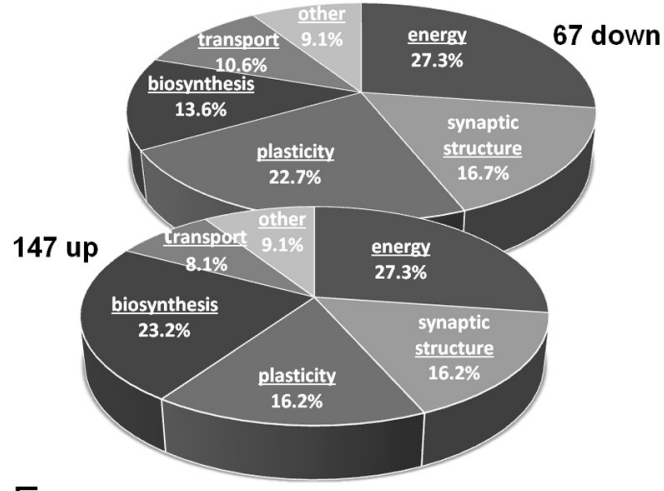

E

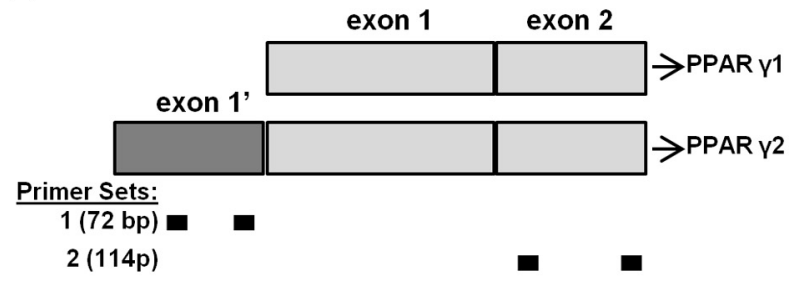

B

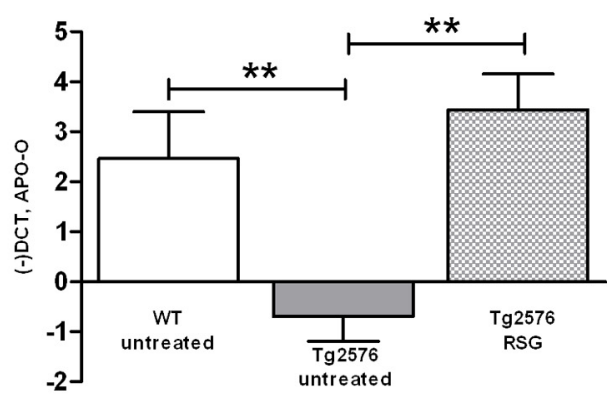

Primer Set 1: exon1'-F exon1'-R Primer Set 2: exon2- $F$ exon2-R
ATGGGTGAAACTCTGGGAGA
GCTCATAGGCAGTGCATCAG

ATGGAAGACCACTCGCATTC AACCATTGGGTCAGCTCTTG

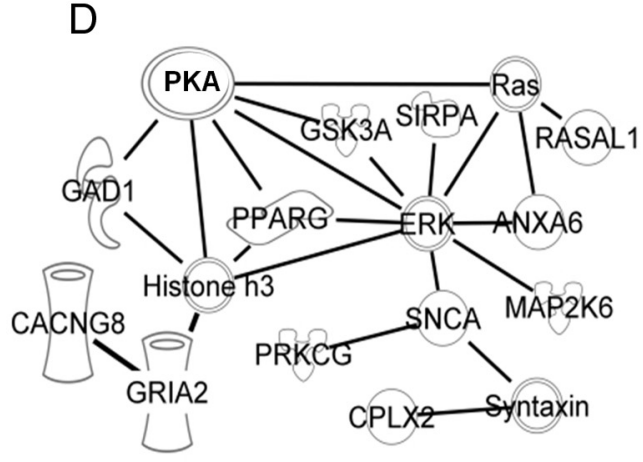

F

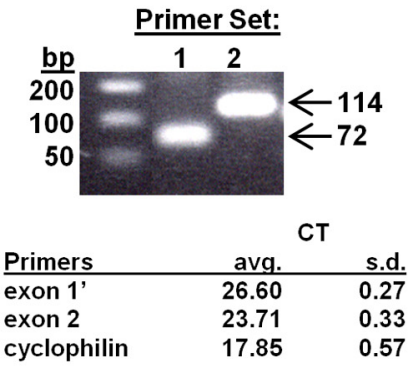

$\triangle C T$ Ratio exon 2/exon 1'

avg. s.d.

Figure 1. Oral delivery of RSG impinges upon CNS PPAR $\gamma$. A, Hippocampal PPAR $\gamma$ binding to its PPRE is enhanced by 1 month RSG treatment. Two-way ANOVA $F_{(3,31)}=9.34$ for treatment; $n 0$ interaction was detected. $\boldsymbol{B}$, One month RSG treatment induces PPAR $\gamma$ target gene expression. The mRNA for the PPRE-containing AP0-0 gene is reduced in untreated Tg2576 compared with WT untreated. RSG normalizes APO-0 expression in Tg2576. One-way ANOVA of $\Delta C_{\mathrm{T}}$ values resulted in $F_{(2.9)}=8.6$. C, Quantitative mass spectrometry reveals Tg2576 hippocampal proteins altered with RSG treatment. All proteins displayed have a Benjamini-Hochberg rank sum $p \leq 0.05$. D, Ingenuity Pathways Analysis of synaptic plasticity proteins identified by quantitative mass spectrometry placed ERK MAPK as a central node in the protein network. ANXA6, Annexin A6; CACNG8, voltage-dependent calcium channel $\gamma$-8 subunit; CPLX2, complexin 2; GAD1, glutamate decarboxylase 1; GR1A2, glutamate receptor subunit 2; GSK3A, glycogen synthase kinase-3 $\alpha$; MAP2K6, dual specificity mitogen-activated protein kinase kinase; PKA, protein kinase A; PPARG, PPAR $\gamma$; PRKCG, protein kinase $\mathrm{C}-\gamma$; RASAL1, RasGAP-activating-like protein 1; SIRPA, signal-regulatory protein $\alpha$; SNCA, $\alpha$-synuclein (see Materials and Methods and www.ingenuity.com for a more detailed description of network statistical calculations, molecule naming, and symbol descriptions).E, PCR strategy to detect PPAR $\gamma 1$ and PPAR $\gamma 2$ gene transcripts in mouse hippocampus.F, Both PPAR $\gamma 1$ and PPAR $\gamma 2$ are detected in hippocampus by conventional PCR (gel image, top). Quantitative PCR shows PPAR $\gamma 1$ mRNA expression is much higher than PPAR $\gamma 2$ in mouse hippocampus. ${ }^{*} p<0.05$, ${ }^{* *} p<0.01$, ${ }^{* * *} p<0.001$.

The zoom scan data were used to calculate the relative abundance ratios of ${ }^{18} \mathrm{O}$-labeled peptide $/{ }^{16} \mathrm{O}$-unlabeled peptide pairs using MassXplorer (Sadygov et al., 2010). Peptides with charge $>3$, false discovery rate $>3 \%,{ }^{18} \mathrm{O} /{ }^{16} \mathrm{O}$ ratios $<0.1$ or $>10$, and reversed sequences were removed from further analysis. Calculated peptide ratios were $\log _{2}$ transformed and mean centered before statistical analysis. Significance was determined by assessed using the Wilcoxon rank-sum test with Benjamini-Hochberg false discovery rate correction for multiple testing comparisons as indicated (Benjamini and Hochberg, 1995).
Data were then analyzed through the use of the extensively curated Ingenuity Pathways Analysis (Ingenuity Systems) with a significance cutoff of $p \leq 0.05$ and $\geq 20 \%$ change in protein expression. Functional Analysis using Gene Ontology classifiers identified the biological functions that were most significant to the dataset. Right-tailed Fisher's exact test was used to calculate a $p$-value determining the probability that each biological function assigned to that dataset is due to chance alone. Network Analysis generates a graphical representation of the molecular relationships between molecules. Molecules are represented as nodes, and the biological relationship between two nodes is represented as a line. All lines are supported by at least one reference from 
the literature, from a textbook, or from canonical information stored in the Ingenuity Knowledge Base. Nodes are displayed with various shapes that represent the functional class of the gene product.

Total $\beta$-amyloid quantification. Cortex from $18 \mathrm{Tg} 2576$ and $18 \mathrm{Tg} 2576$ RSG-treated (male and female) was homogenized in $8 \times$ (volume by wet weight) $5 \mathrm{M}$ guanidine $\mathrm{HCl}, 50 \mathrm{~mm}$ Tris $\mathrm{HCl}, \mathrm{pH}$ 8.0. Signal Select colorimetric sandwich ELISA (BioSource) for either human $\mathrm{A} \beta_{1-40}$ or $\mathrm{A} \beta_{1-42}$ was used in comparison to a standard curve.

Statistics. Statistical analyses were conducted with ANOVA followed by either Bonferroni's or Dunnett's post hoc comparison. Where appropriate, Student's $t$ test was used for pairwise comparison. Significance was set to $p<0.05$.

\section{Results}

Initially we evaluated whether oral RSG treatment increased PPAR $\gamma$ activity in the CNS by measuring hippocampal PPAR $\gamma$ binding to its PPRE. Nuclear extracts prepared from the hippocampus of Tg2576 and WT littermates showed that RSG treatment resulted in a statistically significant $(\sim 30 \%)$ increase in PPAR $\gamma$ DNA binding in both Tg2576 and WT groups (Fig. 1A), confirming that oral RSG is blood-brain barrier permeable (Strum et al., 2007; Festuccia et al., 2008; Diano et al., 2011; Lu et al., 2011; Ryan et al., 2011) and increases steady-state DNA binding. We were unable to affect DNA binding with the PPAR $\gamma$ antagonist GW9662 (data not shown).

Consistent with the prevailing concept that PPAR $\gamma$ binding to PPREs is necessary yet insufficient for regulating target gene expression, we assessed the hippocampal PPAR $\gamma$ transcriptome using quantitative PCR on hippocampal mRNA isolated from mice treated with or without RSG. Expression analysis from a custom array of 45 genes chosen for enrichment in PPREs, demonstrated that 34 were downregulated in untreated $\mathrm{Tg} 2576$ compared with WT and 32 of those were induced by RSG treatment in Tg2576 (Table 1). For example, the PPRE-containing apolipoprotein $\mathrm{O}$ gene $(A P O-O)$ was decreased in untreated Tg2576 compared with WT, and RSG treatment reversed this (Fig. $1 B$ ). As such, untreated Tg2576 mice exhibited a - 1.97-fold-change in APO-O mRNA transcripts compared with WT, and RSG induced a +10.82 -fold increase in this mRNA transcript in Tg2576.

We next probed the hippocampal PPAR $\gamma$ proteome with quantitative mass spectrometry using the stable isotope ${ }^{18} \mathrm{O}-/$ ${ }^{16} \mathrm{O}$-water and LC-MS/MS method (Sadygov et al., 2010; Starkey et al., 2010). This method of differentially labeling and quantifying dentate gyrus proteins from untreated and RSG-treated Tg2576 revealed that PPAR $\gamma$ agonism significantly upregulated 147 proteins and downregulated 67 proteins related to energy, synaptic structure, plasticity, biosynthesis, and transport (Fig. $1 C)$. For example, this approach determined that the PPAR $\gamma$ target gene, APO-O, exhibited 2.9-fold increased protein in RSGtreated Tg2576 compared with untreated Tg2576 (BenjaminiHochberg rank sum $p=0.0015$ ) and the ERK phosphatase PP2A was downregulated by $16 \%$ of untreated Tg2576 (BenjaminiHochberg $p=2.54 \times 10^{-6}$ ).

To evaluate potential functional relationships between the Tg2576 hippocampal proteins whose expression was augmented by RSG treatment, we performed bioinformatics analysis on proteins involved in synaptic plasticity. ERK MAPK emerged as a central node following Ingenuity Pathways Analysis. PPAR $\gamma$ itself was a target regulator of ERK MEK (mitogen-activated protein kinase kinase) in addition to glutamate decarboxylase, GSK3- $\alpha, \alpha$-synuclein, metabotropic glutamate receptor 5, and glutamate receptor 2 (Fig. $1 D$ ).

The mouse PPAR $\gamma$ gene gives rise to two mRNAs (PPAR $\gamma 1$ and PPAR $\gamma 2$ ) that differ only at their $5^{\prime}$ ends (Fig. 1E). The mouse PPAR $\gamma 2$ mRNA encodes an additional 30 aa N-terminal to the first ATG codon of PPAR $\gamma 1$ (Zhu et al., 1995). Our immunoblot analysis of mouse hippocampus from WT or Tg mice treated with any intervention had only revealed a single band at $\sim 67 \mathrm{kDa}$. In an attempt to determine which of the two isoforms was detected by immunoblot, we performed PCR on WT mouse hippocampus using primer pairs that would selectively produce amplicons either only within the PPAR $\gamma 2$-specific exon $1^{\prime}$ (primer set 1 ) or within exon 2 (primer set 2 ) that is common to both PPAR $\gamma 1$ and PPAR $\gamma 2$ (Zhu et al., 1995). This illustrated that both mRNA forms were expressed in the hippocampus (Fig. $1 F$, top). However, quantitative PCR indicated that the ratio of PPAR $\gamma 1$ to PPAR $\gamma 2$ was $>7$ (Fig. $1 F$, bottom). Therefore, immunoblots most likely detected PPAR $\gamma 1$ protein. This was further confirmed by using a PPAR $\gamma 2$-specific antibody (Santa Cruz Biotechnology) to probe mouse hippocampal extracts which failed to produce a signal (data not shown).

We next determined whether there were differences between WT and Tg2576 hippocampal PPAR $\gamma$, Ser84 phosphorylated $\operatorname{PPAR} \gamma(\operatorname{PPPAR} \gamma)$, or subcellular distribution. Quantitative immunoblot analysis of hippocampal cytoplasmic fractions from sham-treated Tg2576, WT, and RSG-treated Tg2576 showed no significant differences in either total or pPPAR $\gamma$ (data not shown). However, Tg2576 hippocampal nuclear fractions contained significantly less PPAR $\gamma$ than WT (Fig. 2A). ERK MAPK phosphorylation of PPAR $\gamma$ at Ser84 is considered inhibitory by decreasing PPAR $\gamma$ transcriptional competency (Camp and Tafuri, 1997; Shao et al., 1998). Although nuclear pPPAR $\gamma$ is lower in untreated Tg2576 (Fig. 2B), nuclear PPAR $\gamma$ transcriptional competency in Tg2576 hippocampus is likely diminished since the ratio of phospho/total PPAR $\gamma$ indicates a net increase in the ERK MAPK phosphorylated, inhibited form of PPAR $\gamma$ (Fig. 2C).

PPAR $\gamma$ agonists have been shown to ameliorate several forms of cognitive deficits in Tg2576 and other AD mouse models (Pedersen et al., 2006; Escribano et al., 2009, 2010; Rodriguez-Rivera et al., 2011). We found that RSG cognitive improvement also ameliorated Tg2576 deficiencies in hippocampal nuclear PPAR $\gamma$ (Fig. $2 A, B$ ). These changes resulted in a ratio of phospho/total PPAR $\gamma$ statistically indistinguishable from WT (Fig. 2C). Finally, quantitative PCR analysis of hippocampal mRNA showed that PPAR $\gamma$ gene expression was reduced in Tg2576 compared with WT and normalized by RSG (Fig. 2D) with an 8.7-fold increase in $\operatorname{PPAR} \gamma$ gene transcripts although PPAR $\gamma$ is not a PPREcontaining gene (Table 1), suggesting that RSG treatment has diverse effects on gene expression. This is further supported by our observation that several genes lacking identifiable PPREs were also induced by RSG treatment (Table 1). In summary, nuclear-PPAR $\gamma$ gene transcripts and protein are deficient in Tg2576 hippocampus and both are normalized with RSG treatment concomitant with reversal of hippocampus-dependent cognitive deficits.

Given the importance of ERK2 MAPK in hippocampusdependent memory (Selcher et al., 2001), including contextual FC, we also evaluated RSG effects on hippocampal ERK2 protein, its phosphorylation (activation) status, and nuclear-cytosolic distribution. Quantitative immunoblot analysis of total-ERK2 in hippocampal nuclear and cytoplasmic fractions showed no significant differences between Tg2576 and WT animals (data not shown). Tg2576 RSG treatment, however, led to increased nuclear ERK2 activity, as noted by an increase in Thr202/Tyr204 phosphorylated ERK2 (pERK2) compared with untreated Tg2576 (Fig. 2E). No significant effects on cytosolic total or pERK2 cytoplasmic samples were found (data not shown). Thus, 
nuclear ERK2 activity in the hippocampus is enhanced during RSG rescue of hippocampus-dependent cognition in Tg2576 mice. Consistent with our previous observation that RSG has no effect on hippocampus-dependent cognition in WT littermates (Rodriguez-Rivera et al., 2011), RSG also had no effect on WT PPAR $\gamma$ or ERK (data not shown).

A recurring concern with thiazolidinediones (TZDs) is whether peripheral administration can actually affect the molecular target PPAR $\gamma$ in the CNS. Thus, to test whether CNS PPAR $\gamma$ mediates RSG cognitive improvement in 9MO Tg2576, we directly injected GW9662 (Leesnitzer et al., 2002) into the lateral ventricles of RSG-treated mice to block CNS PPAR $\gamma$ activity. Such ICV administration of GW9662 has been used to establish that CNS PPAR $\gamma$ mediates RSG effects in animal models of energy balance and feeding behavior (Diano et al., 2011; Ryan et al., 2011). The dose used was based on previous reports of ICV injection of GW9662 to antagonize PPAR $\gamma$ function in the CNS (Maeda et al., 2007; Zhang et al., 2008).

Tg2576 and WT mice were infused with either vehicle or GW9662 4 h before FC training (Fig. 3A). No significant difference in behavior was detected between the groups during training, indicating that ICV injection and PPAR $\gamma$ manipulations do not interfere with behavior during the acquisition phase of this associative learning paradigm (Fig. $3 B$ ). The contextual test for FC memory consolidation performed $24 \mathrm{~h}$ later, further demonstrated that RSG (or ICV injection of vehicle) does not affect WT performance and that RSG-treated Tg2576 now freeze to the same extent as WT in contrast to Tg2576 treated with vehicle alone (Fig. $3 C$ ). These results confirm that RSG treatment ameliorates cognitive deficits in 9MO Tg2576 (Rodriguez-Rivera et al., 2011) and that antagonism of CNS PPAR $\gamma$ in RSG-treated Tg2576 prevents consolidation of the hippocampus-dependent contextual FC memory (Fig. 3C). Neither RSG nor RSG + GW9662 affected WT performance, emphasizing that PPAR $\gamma$ activity is not critical to hippocampus-dependent learning and memory in non-diseased mice. Additional studies in WT mice also demonstrated that RSG treatment does not augment cued FC learning and that ICV-delivered GW9662 alone had no behavioral effect (data not shown). Furthermore, we detected no effect of genotype or treatment in an animals' tendency to flinch, vocalize, or jump to increasing shock intensities during a shock threshold test; indicating that 9MO Tg2576 exhibit equivalent sensory processing of the footshock in the FC paradigm and RSG treatment has no effect on this process in WT or Tg2576 mice (Fig. 3D). Together, these results suggest that RSG rescue of hippocampus-dependent cognitive deficits in Tg2576 $\mathrm{AD}$ mice is mediated by hippocampal PPAR $\gamma$ to compensate for
B

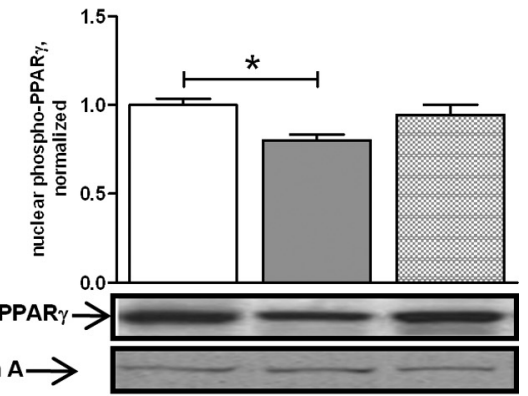

D

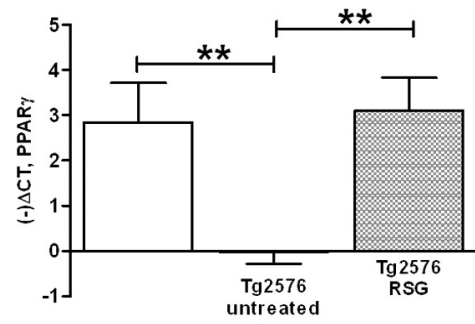

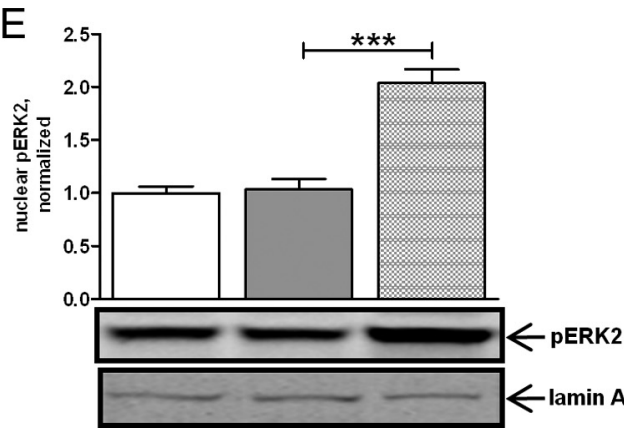

Figure 2. RSG reverses deficits in nuclear PPAR $\gamma$ and increases nuclear ERK2 activity in hippocampus. $A$, Quantitative immunoblotting revealed significant downregulation of nuclear PPAR $\gamma$ in Tg2576 hippocampus. One-way ANOVA $\left(F_{(2,23)}=7.02 ; p=\right.$

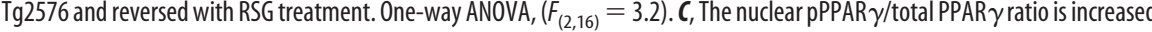

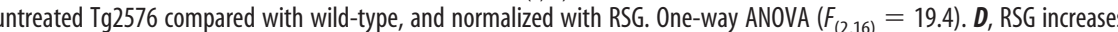
levels expression. Quantitative PCR showed that PPAR $\gamma$ mRNA was reduced in untreated Tg2576 and normalized to WT untreated WT and untreated Tg2576 but increased in RSG-treated Tg2576. One-way ANOVA $\left(F_{(2,17)}=37.3\right)$ and Dunnett's posthoc analysis. Data reported normalized to untreated WT; mean \pm SEM. ${ }^{*} p<0.05,{ }^{* *} p<0.01,{ }^{* * *} p<0.001$.

a signal transduction system that is typically necessary for this form of learning.

Since ERK MAPK is essential for hippocampus-dependent learning and memory in general, and contextual FC in particular, we hypothesized that PPAR $\gamma$ agonism in Tg2576 mice recruits the ERK MAPK pathway to overcome AD-like cognitive deficits in associative learning and memory. Therefore, we evaluated whether PPAR $\gamma$ antagonism with ICV GW9662 affected hippocampal PPAR $\gamma$ and ERK in RSG-treated Tg2576. We killed animals and collected hippocampi to evaluate GW9662 effects 4, 8 , and $16 \mathrm{~h}$ following ICV infusions; if these animals had been FC trained, these time points would have correlated with 0,4 , and $12 \mathrm{~h}$ post-training. Quantitative immunoblot revealed that ICV injection of GW9662 had no significant effect on nuclear or cytosolic forms of total or pPPAR $\gamma$ at the 4 and $16 \mathrm{~h}$ time points compared with vehicle controls (Fig. $4 A-D$ ). However, $8 \mathrm{~h}$ after ICV infusion of GW9662 we observed decreased nuclear PPAR $\gamma$ 

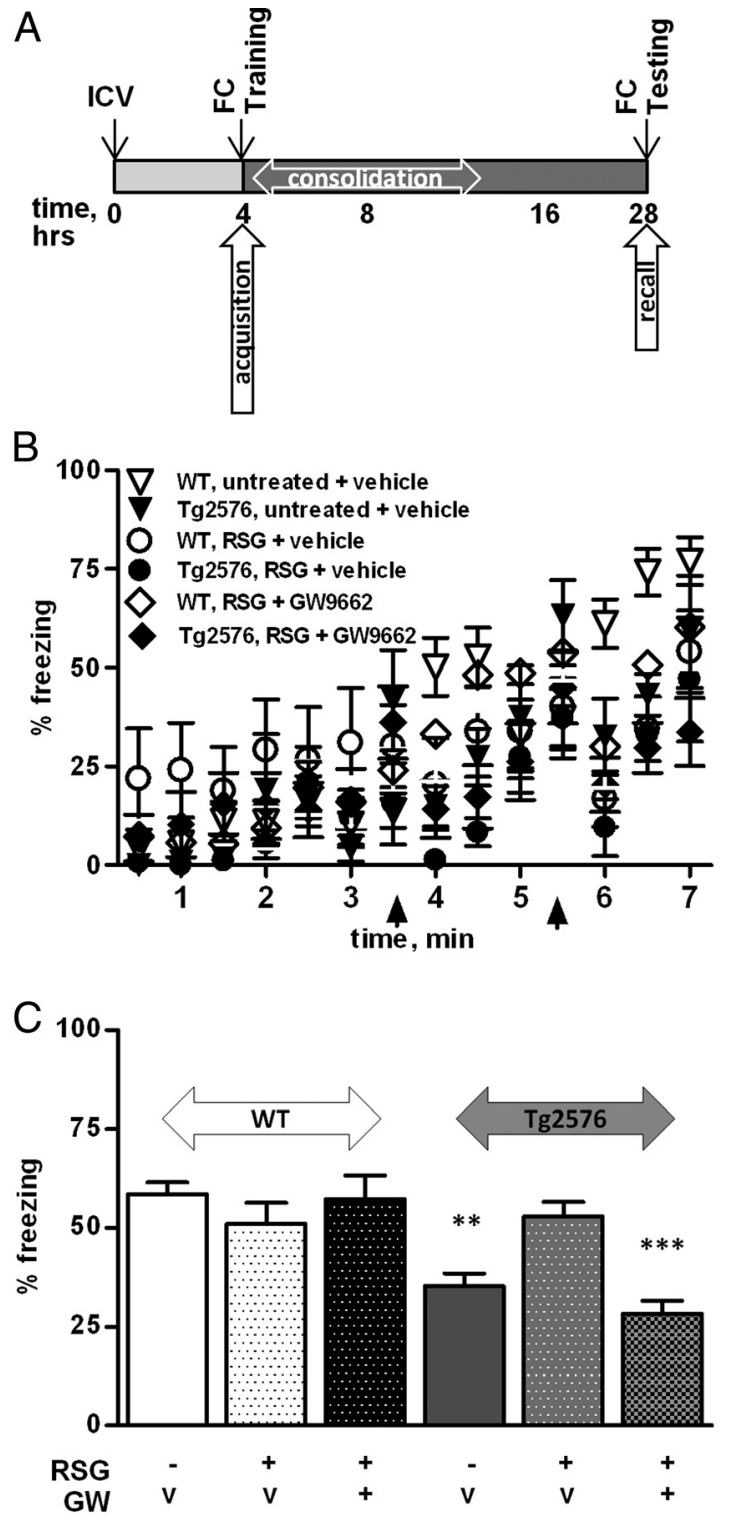

D

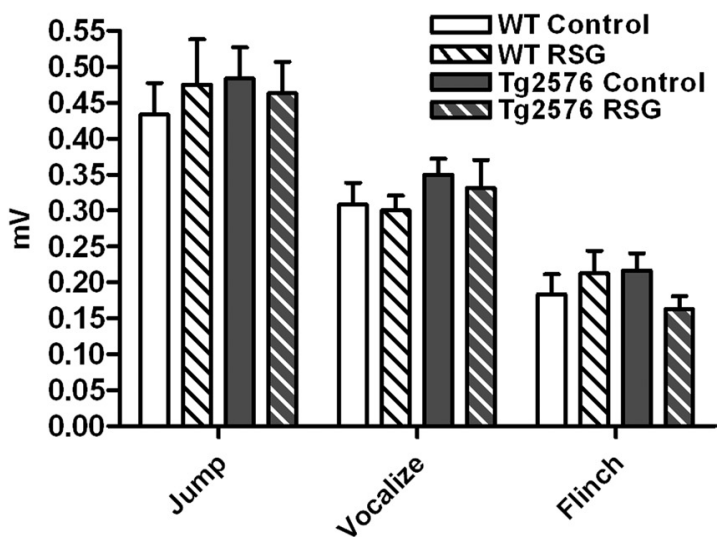

Figure 3. Inhibition of CNS PPAR $\gamma$ blocks RSG-mediated cognitive rescue. Untreated or RSG-treated mice were infused with either vehicle or GW9662 $4 \mathrm{~h}$ before 2-pairing FC training. A, Timeline for FC training and testing following ICV infusion of GW9662. ICV injection was performed $4 \mathrm{~h}$ before the acquisition of $\mathrm{FC}$ learning ( $\mathrm{FC}$ Training). Consolidation proceeds for up to $\sim 10 \mathrm{~h}$ following $\mathrm{FC}$ training. Testing for recall of $\mathrm{FC} 24 \mathrm{~h}$ after training tests for consolidation of $\mathrm{FC}$ learning. $\boldsymbol{B}$, No genotype or treatment effects were detected in the 2-pairing training for
(Fig. 4C) concomitant with increased cytoplasmic PPAR $\gamma$ (Fig. $4 D$ ). Further, cytoplasmic pPPAR $\gamma$ was also increased at $8 \mathrm{~h}$ (Fig. $4 B)$. While total PPAR $\gamma$ decreased $\sim 30 \%$ in the nucleus at this time point, analysis of the phospho/total PPAR $\gamma$ ratio at the $8 \mathrm{~h}$ time point revealed no net change between the nuclear and cytosolic compartments (Student's two-tailed $t$ test $=0.18$, data not shown). These results are consistent with a model in which PPAR $\gamma$ phosphorylation at Ser84 might be instrumental in nuclear export or cytoplasmic retention. In summary, inhibition of CNS PPAR $\gamma$ with GW9662 in RSG-treated Tg2576 mice led to a net decrease in nuclear-PPAR $\gamma$ concomitant with an increase in total and PPPAR $\gamma$ in the cytoplasm suggesting that reversal of cognitive improvement through inhibition of PPAR $\gamma$ involves subcellular redistribution of the protein.

Since the maximal effect of GW9662 on nuclear PPAR $\gamma$ was achieved $8 \mathrm{~h}$ after ICV injection, we evaluated whether nuclear ERK2 activity was also affected at this time point. As might be expected, GW9662 antagonism of CNS PPAR $\gamma$ resulted in no change in total ERK2 but decreased nuclear ERK2 activation (one-way ANOVA: $\left(F_{(2,14)}=6.01, F_{(2,15)}=0.42(p<0.05)\right)$ for total ERK and pERK, respectively). Because ERK activation and the ERK2 isoform has been shown to be necessary for FC consolidation (Atkins et al., 1998; Selcher et al., 2001), our findings that PPAR $\gamma$ antagonism both reverses RSG effects on FC performance and nuclear ERK activity supports our interpretation that cognitive improvement in Tg2576 with RSG treatment results from PPAR $\gamma$ effects on ERK2 MAPK activity in the hippocampus.

These RSG-mediated effects are consistent with the notion that RSG crosses the blood-brain barrier to activate CNS PPAR $\gamma$ (Willson et al., 1996; Strum et al., 2007; Festuccia et al., 2008; Diano et al., 2011; Lu et al., 2011; Ryan et al., 2011). Further, RSG increased both WT and Tg2576 hippocampal PPAR $\gamma$ DNA binding activity indicating that RSG effects in Tg2576 brain are not due to compromised BBB permeability. Finally, ICV administration of the specific PPAR $\gamma$ full antagonist GW9662 (Leesnitzer et al., 2002) reversed RSG cognitive improvement strongly implicates CNS PPAR $\gamma$.

Last, we assessed whether cognitive improvement via PPAR $\gamma$ agonism correlates with altered $\mathrm{A} \beta$ accumulation. Total $\mathrm{A} \beta_{1-40}$ and $\mathrm{A} \beta_{1-42}$ were quantified by dissolving cortical tissue directly in guanidine- $\mathrm{HCl}$ to extract all forms of $\mathrm{A} \beta$ from untreated Tg2476 and RSG-treated Tg2576 that were ICV-injected with either vehicle or GW9662. Neither 1 month RSG treatment nor acute GW9662 PPAR $\gamma$ inhibition $(8 \mathrm{~h})$ significantly altered total $\mathrm{A} \beta_{1-40}$, or $\mathrm{A} \beta_{1-42}$ (Table 2). Therefore, neither RSG PPAR $\gamma$ agonism nor GW9662 PPAR $\gamma$ antagonism influenced A $\beta$ accumulation in this animal model. Since we are focused on elucidating cognitive rescue mechanisms downstream of $A \beta$ toxicity, we did not further characterize effects of RSG treatment on $\mathrm{A} \beta$ pathol-

\footnotetext{
$\leftarrow$

FC. Repeated-measures two-way ANOVA $\left(F_{(1,1,1)}=2.49\right.$ and 2.00$)$ for genotype and treatment respectively; no interaction was detected. Data reported as mean percentage freezing \pm SEM for each 30 s epoch. Vertical arrows on timeline denote the epoch within which the footshock was delivered during $\mathrm{FC}$ training. $\boldsymbol{C}$, In the contextual test for $\mathrm{FC}$, two-way ANOVA detected a genotype effect but no treatment effect or interaction $\left(F_{(2,1,2)}=0.778\right.$ and 29.72) for genotype and treatment. Therefore, untreated Tg2576 (RSG - ) vehicle-infused (GW V) Tg2576 and RSGtreated (RSG +) Tg2576 ICV infused with GW9662 (GW +) froze significantly less. Neither RSG nor GW9662 had an effect on performance of WT. Data reported as mean percentage total freezing \pm SEM. ${ }^{* * *} p<0.0001$ compared with RSG-vehicle groups; ${ }^{* *} p<0.01$ compared with vehicle-infused groups. V, Vehicle-infused. D, No significant genotype or treatment effect detected in 9MO WT and Tg2576, untreated or RSG-treated, with two-way ANOVA in the shock threshold test.
} 

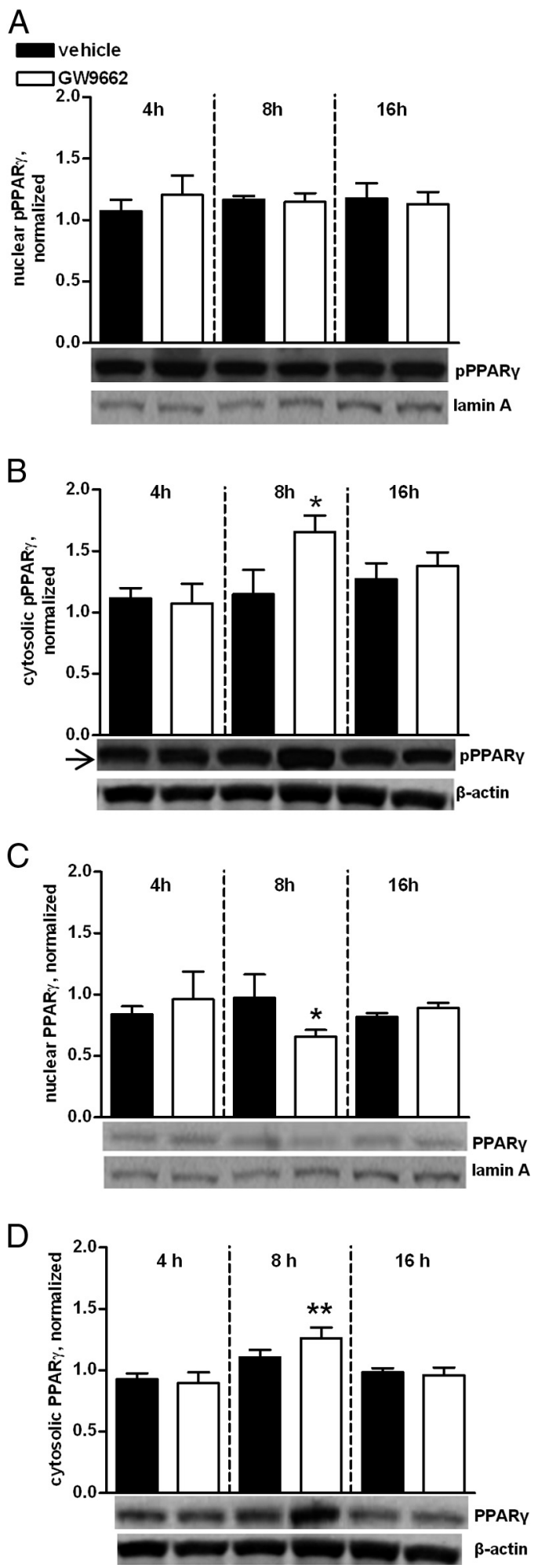

Figure 4. Hippocampal nuclear ERK2 activity is modulated by PPAR $\gamma$. A-D, Quantitative immunoblot of hippocampal total and pPPAR $\gamma$ in nuclear and cytoplasmic compartments from RSG-treated Tg2576 ICV infused with vehicle or GW9662. ICV injection of GW9662 analyzed by one-way ANOVA detected no effect on nuclear pPPAR $\gamma$ at any time point $(A)\left(F_{(6,20)}=0.49\right)$, but did result in a significant increase in cytosolic pPPAR $\gamma$ by $8 \mathrm{~h}(\boldsymbol{B})\left(F_{(6,24)}=3.16\right) . \boldsymbol{C}, \boldsymbol{D}$, One-way ANOVA and Dunnett's post hoc analysis revealed that ICV injection of GW9662 led to a significant decrease in nuclear PPAR $\gamma$ levels $8 \mathrm{~h}$ after infusion $(\boldsymbol{C})$, with a concomitant increase in cytosolic PPAR $\gamma(\boldsymbol{D})\left(F_{(6,30)}=2.83\right.$ and 3.38) for $\boldsymbol{C}$ and $\boldsymbol{D}$, respectively. Data normalized to RSG-treated Tg2576 and expressed as mean \pm SEM. ${ }^{*} p<0.05,{ }^{* *} p<0.01,{ }^{* * *} p<0.001$.
Table 2. Quantification of total cortical A $\beta$ in 9MO RSG-treated Tg2576

\begin{tabular}{rrrcl}
\hline & $\operatorname{Tg} 2576$ & $\operatorname{Tg} 2576$, RSG & Tg2576, RSG + vehicle & Tg2576, RSG + GW9662 \\
\hline$A \beta 42$ & $187.6 \pm 32.0$ & $162.5 \pm 39.4$ & $195.3 \pm 49.6$ & $201 \pm 58.2$ \\
$A \beta 40$ & $360 \pm 65.2$ & $444.1 \pm 76.0$ & $463 \pm 120$ & $441 \pm 126$ \\
\hline
\end{tabular}

Data are reported as mean \pm SEM picomoles of $A \beta$ per gram wet weight tissue. One-way $A N O V A$ analysis of $A \beta_{1-40}$ and $A \beta_{1-42}\left(F_{(3,43)}=0.32\right.$ and $\left.=0.15\right)$, respectively.

ogy although there are reports of $\mathrm{A} \beta$ mechanisms (MandrekarColucci et al., 2012).

\section{Discussion}

We and others have previously shown that PPAR $\gamma$ agonists improve cognitive performance in mouse models of $\mathrm{AD}$, mainly in tasks affected in human AD (Hamann et al., 2002; Pedersen et al., 2006; Hort et al., 2007; Hoefer et al., 2008; Escribano et al., 2010; Rodriguez-Rivera et al., 2011). It is also well established that hippocampal ERK MAPK is required for many of these forms of learning and memory (Sweatt, 2004). In these contexts, the current study addressed the convergence of the ERK MAPK and $\operatorname{PPAR} \gamma$ signaling pathways in Tg2576 mice following cognitive improvement with RSG.

Initially, we evaluated hippocampal PPAR $\gamma$ in Tg2576 and WT littermates either untreated or treated with oral RSG for 1 month between $8 \mathrm{MO}$ and 9MO. RSG treatment of Tg2576 mice significantly enhanced hippocampal PPAR $\gamma$ DNA binding, mRNA, and protein. PPAR $\gamma$ phosphorylation at Ser84 has been shown to inhibit transcriptional competency (Camp and Tafuri, 1997). We found that the ratio of pPPAR $\gamma /$ total PPAR $\gamma$ in untreated $\mathrm{Tg} 2576$ hippocampus nuclear fractions was significantly elevated, indicative of net PPAR $\gamma$ inhibition, while RSG treatment normalized this ratio to WT level.

We discovered that concomitant with RSG cognitive enhancement, the hippocampal PPAR $\gamma$ transcriptome and proteome converge with the ERK MAPK cascade at several levels. First, the majority of PPRE-containing target genes induced by RSG treatment also contain CREs suggesting that some PPAR $\gamma$ target genes are also CREB target genes which themselves are highly regulated by ERK MAPK during memory consolidation (Guzowski and McGaugh, 1997; Ahi et al., 2004). Second, an unbiased proteomics and bioinformatics analysis of the dentate gyrus from untreated and RSG-treated Tg2576 found that ERK MAPK was a central, integrative node of the plasticity proteins augmented by RSG. Third, RSG-mediated changes in hippocampal PPAR $\gamma$ and ERK were reversed when RSG-treated Tg2576 memory consolidation was blocked by an irreversible, selective PPAR $\gamma$ full antagonist (GW9662). Thus, there is a coordinate relationship between $\operatorname{PPAR} \gamma$ transcriptional competency and pERK that is reciprocally affected in response to chronic activation, compared with acute inhibition, of PPAR $\gamma$. Finally, CREB-binding protein (CBP) was markedly induced during RSG cognitive enhancement. CBP can rescue learning and memory deficits in $\mathrm{AD}$ mouse models (Caccamo et al., 2010), is a nuclear coactivator of PPAR $\gamma$ (Bugge et al., 2009; Inoue et al., 2012) and CREB (Klein et al., 2005), and is thus well positioned to integrate the convergence of the PPAR $\gamma$ and ERK MAPK pathways.

From our data, we elaborate on one of many examples for convergent PPAR $\gamma$ and ERK pathway integration: RSG treatment impinged upon the protein sumoylation system. Protein sumoylation often leads to the functional inhibition of the target protein, e.g., MEK, the upstream kinase activator of ERK (Kubota et al., 2011). This post-translational inhibitory modification is reversibly regulated by the SENP family of SUMO proteases. A 
scenario can be considered in which increased Tg2576 hippocampal protein sumoylation (McMillan et al., 2011) leads to inhibition of MEK, thereby preventing proper ERK activation during memory consolidation. Elevated sumoylation could also account for the observed reduction in PPAR $\gamma$ transcriptional activity (Floyd and Stephens, 2012) as well as the PPAR $\gamma$ hippocampal coregulator PGC1- $\alpha$ (Rytinki and Palvimo, 2009) and the ERK target CBP (Kuo et al., 2005). RSG-mediated induction of SENP8 gene expression could conceivably contribute to disinhibition of the PPAR $\gamma$ transcriptome and the ERK MAPK cascade. Likewise, RSG induction of CBP, cyclin-dependent kinase 2 , and nucleosomal assembly protein 1-like 1 would further contribute to PPAR $\gamma$ and ERK-dependent transcription by providing transcription coregulators and enhancing ERK nuclear translocation (Okada et al., 2011; Plotnikov et al., 2011). This hypothetical scenario built upon the observed PPAR $\gamma$ transcriptome supports our model that PPAR $\gamma$ agonism serves to integrate the ERK and PPAR $\gamma$ signaling pathways to facilitate hippocampal memory consolidation.

Analysis of the Tg2576 hippocampal proteome from untreated versus RSG-treated animals also supports the notion that PPAR $\gamma$ agonism serves to integrate the ERK and PPAR $\gamma$ signaling pathways. We found that RSG led to the upregulation of 147 proteins and downregulation of 67 proteins in Tg2576 dentate gyrus that can be functionally categorized into energy, biosynthesis, synaptic structure or plasticity; consistent with many of the proteins found affected in human AD hippocampus with similar approaches (Sultana et al., 2007; Di Domenico et al., 2011). Again, several of the identified proteins were related to the ERK MAPK cascade (e.g., GluR2, mGluR5, PKC $\gamma$ ) (Neary et al., 1999; Schroeter et al., 2007; Ménard and Quirion, 2012). If 9MO $\mathrm{Tg} 2576$ recapitulates a relevant and diagnosable stage of human $\mathrm{AD}, \mathrm{PPAR} \gamma$ agonism to selectively impinge upon the ERK MAPK cascade represents a disease modifying intervention for humans. Furthermore, given the adverse side effects attributed to RSG full agonism of PPAR $\gamma$, it will be important to test alternative TZDs such as pioglitazone as well as next-generation $\operatorname{PPAR} \gamma$ nonagonist and partial agonist ligands (Choi et al., 2010, 2011; Vidović et al., 2011).

GW9662 PPAR $\gamma$ antagonism in RSG-treated AD mice mimics the effect of ERK MAPK inhibitors on contextual FC in WT rodents (Atkins et al., 1998) further supporting the model that $\operatorname{PPAR} \gamma$ can harnesses a dysregulated ERK MAPK pathway to overcome AD-like cognitive deficits in Tg2576 mice. At the biochemical level, GW9662 reversed the effects of RSG on nuclear $\operatorname{PPAR} \gamma$ and ERK activity in Tg2576 hippocampus with a time course that suggests GW9662 interferes with FC consolidation through effects on ERK via PPAR $\gamma$.

GW9662 also led to elevated cytoplasmic pPPAR $\gamma$, indicating that GW9662 reversed RSG effects on nuclear PPAR $\gamma$ and promoted cytosolic redistribution of PPAR $\gamma$. Since PPAR $\gamma$ Ser84 phosphorylation also promotes the rapid turnover of PPAR $\gamma$ through targeted ubiquitination, sumoylation, and proteosomal degradation (Genini and Catapano, 2006), this may account for the relatively rapid recovery (16 h) from GW9662. While our methodology cannot address PPAR $\gamma$ nuclear/cytosol shuttling or turnover, it can be said that GW9662 reversal of RSG cognitive improvement leads to reduced PPAR $\gamma$ nuclear localization and increased inhibitory phosphorylation accompanied by reduced nuclear ERK activity.

The ERK MAPK cascade has been shown to regulate PPAR $\gamma$ both through phosphorylation and nuclear/cytosol trafficking via interaction with MEK-ERK complexes which themselves shuttle in and out of the nucleus (Burgermeister et al., 2007; von Knethen et al., 2010). We found that RSG increased nuclear ERK activity concomitant with a decrease in ERK-mediated pPPAR $\gamma$. This at first appears illogical but one possible consequence of RSG cognitive enhancement is concurrent effects on overall ERK activity as well as ERK substrate selectivity. We suggest that following RSG treatment, pERK performs many functions, some of which are in series and in parallel with PPAR $\gamma$ such that not all pERK directly affects PPAR $\gamma$ phosphorylation because some pERK is executing additional cognitive-enhancing functions. An alternative mechanism might be the upregulation of phosphatases that act upon PPAR $\gamma$ that lead to decreased PPPAR $\gamma$. Our observation that serine/threonine protein phosphatase 1 (PP1) $\alpha$ and $\gamma$ gene transcripts are upregulated in RSG-treated Tg2576 (Table 1) is consistent with this mechanism, although the PPAR $\gamma$ phosphatase has yet to be identified.

Although many examples of TZDs increasing pERK exist in the literature, the mechanism remains poorly defined (Gardner et al., 2003; Kim et al., 2003; Rosa et al., 2008). The following model attempts to integrate our data within a framework of potential relationships with the ERK MAPK cascade and ERK molecular mechanisms gleaned from the annotated literature. RSG cognitive enhancement may reflect a feed forward loop that begins with RSG-mediated PPAR $\gamma$ target gene induction, e.g., casein kinase II subunit II $\alpha$ (CK2 $\alpha)$ (Table 1), which in turn stimulates ERK nuclear translocation (Plotnikov et al., 2011). We detected decreased PP2A by mass spectrometry similar to TZD (pioglitazone) effects during adipocyte differentiation (Altiok et al., 1997). Since PP2A specifically dephosphorylates and inactivates pERK (Alessi et al., 1995; Hu et al., 2009; Puustinen et al., 2009), decreased PP2A would be predicted to lead to a net increase in pERK as we found (Fig. 2E). These results suggest potential coordinate effects of decreased PP2A and increased CK2 $\alpha$ on nuclear ERK activity. Furthermore, cross-regulatory feed forward loops have been extensively described in that some transcription factors induced by PPAR $\gamma$ also bind to the PPAR $\gamma$ gene promoter to increase its expression. Our finding of increased PPAR $\gamma$ transcripts and protein in RSG-treated Tg2576 support this notion. PPAR $\gamma$, in turn, may then mediate the induction of other transcription factors and target genes that integrate the PPAR $\gamma$ transcriptome with the ERK MAPK cascade. One example of this comes from the C/EBP-PPAR $\gamma$ field (Wu et al., 1995, 1999; Lefterova et al., 2008).

Enhanced cognition in AD mice with RSG PPAR $\gamma$ agonism, coupled with our finding that neither PPAR $\gamma$ agonism nor antagonism affected WT performance, positions this nuclear receptor as a potential therapeutic target for the human disease. This idea is strengthened by the fact that $\operatorname{PPAR} \gamma$ is dysregulated in $\mathrm{AD}$ brain and certain polymorphisms in the PPAR $\gamma$ gene are associated with increased risk for the disease (Kitamura et al., 1999; Scacchi et al., 2007). Furthermore, our discovery that the hippocampal PPAR $\gamma$ transcriptome and proteome converge with the ERK MAPK cascade at several levels, combined with the reciprocal effects of RSG and GW9662 on PPAR $\gamma$ and ERK activity and localization, suggest a multifaceted regulatory relationship warranting further investigation.

\section{References}

Ahi J, Radulovic J, Spiess J (2004) The role of hippocampal signaling cascades in consolidation of fear memory. Behav Brain Res 149:17-31. CrossRef Medline

Alessi DR, Gomez N, Moorhead G, Lewis T, Keyse SM, Cohen P (1995) Inactivation of $\mathrm{p} 42 \mathrm{MAP}$ kinase by protein phosphatase $2 \mathrm{~A}$ and a protein 
tyrosine phosphatase, but not CL100, in various cell lines. Curr Biol 5:283-295. CrossRef Medline

Altiok S, Xu M, Spiegelman BM (1997) PPARgamma induces cell cycle withdrawal: inhibition of E2F/DP DNA-binding activity via downregulation of PP2A. Genes Dev 11:1987-1998. CrossRef Medline

Atkins CM, Selcher JC, Petraitis JJ, Trzaskos JM, Sweatt JD (1998) The MAPK cascade is required for mammalian associative learning. Nat Neurosci 1:602-609. CrossRef Medline

Bell KA, O’Riordan KJ, Sweatt JD, Dineley KT (2004) MAPK recruitment by beta-amyloid in organotypic hippocampal slice cultures depends on physical state and exposure time. J Neurochem 91:349-361. CrossRef Medline

Benjamini Y, Hochberg Y (1995) Controlling the false discovery rate: A practical and powerful approach to multiple testing. J R Stat Soc Ser B 57:289-300.

Bugge A, Grøntved L, Aagaard MM, Borup R, Mandrup S (2009) The PPARgamma2 A/B-domain plays a gene-specific role in transactivation and cofactor recruitment. Mol Endocrinol 23:794-808. CrossRef Medline

Burgermeister E, Chuderland D, Hanoch T, Meyer M, Liscovitch M, Seger R (2007) Interaction with MEK causes nuclear export and downregulation of peroxisome proliferator-activated receptor gamma. Mol Cell Biol 27: 803-817. CrossRef Medline

Caccamo A, Maldonado MA, Bokov AF, Majumder S, Oddo S (2010) CBP gene transfer increases BDNF levels and ameliorates learning and memory deficits in a mouse model of Alzheimer's disease. Proc Natl Acad Sci U S A 107:22687-22692. CrossRef Medline

Camp HS, Tafuri SR (1997) Regulation of peroxisome proliferatoractivated receptor gamma activity by mitogen-activated protein kinase. J Biol Chem 272:10811-10816. CrossRef Medline

Choi JH, Banks AS, Estall JL, Kajimura S, Boström P, Laznik D, Ruas JL, Chalmers MJ, Kamenecka TM, Blüher M, Griffin PR, Spiegelman BM (2010) Anti-diabetic drugs inhibit obesity-linked phosphorylation of PPARgamma by Cdk5. Nature 466:451-456. CrossRef Medline

Choi JH, Banks AS, Kamenecka TM, Busby SA, Chalmers MJ, Kumar N, Kuruvilla DS, Shin Y, He Y, Bruning JB, Marciano DP, Cameron MD, Laznik D, Jurczak MJ, Schürer SC, Vidović D, Shulman GI, Spiegelman BM, Griffin PR (2011) Antidiabetic actions of a non-agonist PPARgamma ligand blocking Cdk5-mediated phosphorylation. Nature 477: 477-481. CrossRef Medline

Clark WG, Vivonia CA, Baxter CF (1968) Accurate freehand injection into the lateral brain ventricle of the conscious mouse. J Appl Physiol 25:319321. Medline

Costello DA, O'Leary DM, Herron CE (2005) Agonists of peroxisome proliferator-activated receptor-gamma attenuate the Abeta-mediated impairment of LTP in the hippocampus in vitro. Neuropharmacology 49:359-366. CrossRef Medline

Diano S, Liu ZW, Jeong JK, Dietrich MO, Ruan HB, Kim E, Suyama S, Kelly K, Gyengesi E, Arbiser JL, Belsham DD, Sarruf DA, Schwartz MW, Bennett AM, Shanabrough M, Mobbs CV, Yang X, Gao XB, Horvath TL (2011) Peroxisome proliferation-associated control of reactive oxygen species sets melanocortin tone and feeding in diet-induced obesity. Nat Med 17:1121-1127. CrossRef Medline

Di Domenico F, Sultana R, Barone E, Perluigi M, Cini C, Mancuso C, Cai J, Pierce WM, Butterfield DA (2011) Quantitative proteomics analysis of phosphorylated proteins in the hippocampus of Alzheimer's disease subjects. J Proteomics 74:1091-1103. CrossRef Medline

Dineley KT, Westerman M, Bui D, Bell K, Ashe KH, Sweatt JD (2001a) Beta-amyloid activates the mitogen-activated protein kinase cascade via hippocampal alpha7 nicotinic acetylcholine receptors: in vitro and in vivo mechanisms related to Alzheimer's disease. J Neurosci 21:4125-4133. Medline

Dineley KT, Weeber EJ, Atkins C, Adams JP, Anderson AE, Sweatt JD (2001b) Leitmotifs in the biochemistry of LTP induction: amplification, integration and coordination. J Neurochem 77:961-971. CrossRef Medline

Dineley KT, Xia X, Bui D, Sweatt JD, Zheng H (2002) Accelerated plaque accumulation, associative learning deficits and upregulation of alpha 7 nicotinic receptor protein in transgenic mice co-expressing mutant human presenilin 1 and amyloid precursor proteins. J Biol Chem 277: 22768-22780. CrossRef Medline

Escribano L, Simón AM, Pérez-Mediavilla A, Salazar-Colocho P, Del Río J,
Frechilla D (2009) Rosiglitazone reverses memory decline and hippocampal glucocorticoid receptor down-regulation in an Alzheimer's disease mouse model. Biochem Biophys Res Commun 379:406-410. CrossRef Medline

Escribano L, Simón AM, Gimeno E, Cuadrado-Tejedor M, López de Maturana R, García-Osta A, Ricobaraza A, Pérez-Mediavilla A, Del Río J, Frechilla D (2010) Rosiglitazone rescues memory impairment in Alzheimer's transgenic mice: mechanisms involving a reduced amyloid and tau pathology. Neuropsychopharmacology 35:1593-1604. CrossRef Medline

Festuccia WT, Oztezcan S, Laplante M, Berthiaume M, Michel C, Dohgu S, Denis RG, Brito MN, Brito NA, Miller DS, Banks WA, Bartness TJ, Richard D, Deshaies Y (2008) Peroxisome proliferator-activated receptorgamma-mediated positive energy balance in the rat is associated with reduced sympathetic drive to adipose tissues and thyroid status. Endocrinology 149:2121-2130. CrossRef Medline

Floyd ZE, Stephens JM (2012) Controlling a master switch of adipocyte development and insulin sensitivity: covalent modifications of PPARgamma. Biochim Biophys Acta 1822:1090-1095. CrossRef Medline

Gardner OS, Dewar BJ, Earp HS, Samet JM, Graves LM (2003) Dependence of peroxisome proliferator-activated receptor ligand-induced mitogenactivated protein kinase signaling on epidermal growth factor receptor transactivation. J Biol Chem 278:46261-46269. CrossRef Medline

Genini D, Catapano CV (2006) Control of peroxisome proliferatoractivated receptor fate by the ubiquitinproteasome system. J Recept Signal Transduct Res 26:679-692. CrossRef Medline

Guzowski JF, McGaugh JL (1997) Antisense oligodeoxynucleotidemediated disruption of hippocampal cAMP response element binding protein levels impairs consolidation of memory for water maze training. Proc Natl Acad Sci U S A 94:2693-2698. CrossRef Medline

Hamann S, Monarch ES, Goldstein FC (2002) Impaired fear conditioning in Alzheimer's disease. Neuropsychologia 40:1187-1195. CrossRef Medline

Hoefer M, Allison SC, Schauer GF, Neuhaus JM, Hall J, Dang JN, Weiner MW, Miller BL, Rosen HJ (2008) Fear conditioning in frontotemporal lobar degeneration and Alzheimer's disease. Brain 131:1646-1657. CrossRef Medline

Hort J, Laczó J, Vyhnálek M, Bojar M, Bures J, Vlcek K (2007) Spatial navigation deficit in amnestic mild cognitive impairment. Proc Natl Acad Sci U S A 104:4042-4047. CrossRef Medline

Hsiao K, Chapman P, Nilsen S, Eckman C, Harigaya Y, Younkin S, Yang F, Cole G (1996) Correlative memory deficits, Abeta elevation, and amyloid plaques in transgenic mice. Science 274:99-102. CrossRef Medline

Hu X, Wu X, Xu J, Zhou J, Han X, Guo J (2009) Src kinase up-regulates the ERK cascade through inactivation of protein phosphatase $2 \mathrm{~A}$ following cerebral ischemia. BMC Neurosci 10:74. CrossRef Medline

Inoue $\mathrm{M}$, Tanabe $\mathrm{H}$, Matsumoto A, Takagi M, Umegaki K, Amagaya S, Takahashi J (2012) Astaxanthin functions differently as a selective peroxisome proliferator-activated receptor gamma modulator in adipocytes and macrophages. Biochem Pharmacol 84:692-700. CrossRef Medline

Kim EJ, Park KS, Chung SY, Sheen YY, Moon DC, Song YS, Kim KS, Song S, Yun YP, Lee MK, Oh KW, Yoon DY, Hong JT (2003) Peroxisome proliferator-activated receptor-gamma activator 15-deoxy-Delta12,14prostaglandin J2 inhibits neuroblastoma cell growth through induction of apoptosis: association with extracellular signal-regulated kinase signal pathway. J Pharmacol Exp Ther 307:505-517. CrossRef Medline

Kitamura Y, Shimohama S, Koike H, Kakimura J, Matsuoka Y, Nomura Y, Gebicke-Haerter PJ, Taniguchi T (1999) Increased expression of cyclooxygenases and peroxisome proliferator-activated receptor-gamma in Alzheimer's disease brains. Biochem Biophys Res Commun 254:582-586. CrossRef Medline

Klein FA, Atkinson RA, Potier N, Moras D, Cavarelli J (2005) Biochemical and NMR mapping of the interface between CREB-binding protein and ligand binding domains of nuclear receptor: beyond the LXXLL motif. J Biol Chem 280:5682-5692. Medline

Kubota Y, O'Grady P, Saito H, Takekawa M (2011) Oncogenic Ras abrogates MEK SUMOylation that suppresses the ERK pathway and cell transformation. Nat Cell Biol 13:282-291. CrossRef Medline

Kuo HY, Chang CC, Jeng JC, Hu HM, Lin DY, Maul GG, Kwok RP, Shih HM (2005) SUMO modification negatively modulates the transcriptional activity of CREB-binding protein via the recruitment of Daxx. Proc Natl Acad Sci U S A 102:16973-16978. CrossRef Medline 
Leesnitzer LM, Parks DJ, Bledsoe RK, Cobb JE, Collins JL, Consler TG, Davis RG, Hull-Ryde EA, Lenhard JM, Patel L, Plunket KD, Shenk JL, Stimmel JB, Therapontos C, Willson TM, Blanchard SG (2002) Functional consequences of cysteine modification in the ligand binding sites of peroxisome proliferator activated receptors by GW9662. Biochemistry 41: 6640-6650. CrossRef Medline

Lefterova MI, Zhang Y, Steger DJ, Schupp M, Schug J, Cristancho A, Feng D, Zhuo D, Stoeckert CJ Jr, Liu XS, Lazar MA (2008) PPARgamma and C/EBP factors orchestrate adipocyte biology via adjacent binding on a genome-wide scale. Genes Dev 22:2941-2952. CrossRef Medline

Lu M, Sarruf DA, Talukdar S, Sharma S, Li P, Bandyopadhyay G, Nalbandian S, Fan W, Gayen JR, Mahata SK, Webster NJ, Schwartz MW, Olefsky JM (2011) Brain PPAR-gamma promotes obesity and is required for the insulin-sensitizing effect of thiazolidinediones. Nat Med 17:618-622. CrossRef Medline

Maeda T, Kiguchi N, Fukazawa Y, Yamamoto A, Ozaki M, Kishioka S (2007) Peroxisome proliferator-activated receptor gamma activation relieves expression of behavioral sensitization to methamphetamine in mice. Neuropsychopharmacology 32:1133-1140. CrossRef Medline

Mandrekar-Colucci S, Karlo JC, Landreth GE (2012) Mechanisms underlying the rapid peroxisome proliferator-activated receptor-gammamediated amyloid clearance and reversal of cognitive deficits in a murine model of Alzheimer's disease. J Neurosci 32:10117-10128. CrossRef Medline

McMillan LE, Brown JT, Henley JM, Cimarosti H (2011) Profiles of SUMO and ubiquitin conjugation in an Alzheimer's disease model. Neurosci Lett 502:201-208. CrossRef Medline

Ménard C, Quirion R (2012) Successful cognitive aging in rats: a role for mGluR5 glutamate receptors, homer 1 proteins and downstream signaling pathways. PLoS One 7:e28666. CrossRef Medline

Neary JT, Kang Y, Bu Y, Yu E, Akong K, Peters CM (1999) Mitogenic signaling by ATP/P2Y purinergic receptors in astrocytes: involvement of a calcium-independent protein kinase $\mathrm{C}$, extracellular signal-regulated protein kinase pathway distinct from the phosphatidylinositol-specific phospholipase C/calcium pathway. J Neurosci 19:4211-4220. Medline

Okada M, Hozumi Y, Ichimura T, Tanaka T, Hasegawa H, Yamamoto M, Takahashi N, Iseki K, Yagisawa H, Shinkawa T, Isobe T, Goto K (2011) Interaction of nucleosome assembly proteins abolishes nuclear localization of DGKzeta by attenuating its association with importins. Exp Cell Res 317:2853-2863. CrossRef Medline

Papageorgiou E, Pitulis N, Msaouel P, Lembessis P, Koutsilieris M (2007) The non-genomic crosstalk between PPAR-gamma ligands and ERK1/2 in cancer cell lines. Expert Opin Ther Targets 11:1071-1085. CrossRef Medline

Pedersen WA, McMillan PJ, Kulstad JJ, Leverenz JB, Craft S, Haynatzki GR (2006) Rosiglitazone attenuates learning and memory deficits in Tg2576 Alzheimer mice. Exp Neurol 199:265-273. CrossRef Medline

Plotnikov A, Chuderland D, Karamansha Y, Livnah O, Seger R (2011) Nuclear extracellular signal-regulated kinase 1 and 2 translocation is mediated by casein kinase 2 and accelerated by autophosphorylation. Mol Cell Biol 31:3515-3530. CrossRef Medline

Puustinen P, Junttila MR, Vanhatupa S, Sablina AA, Hector ME, Teittinen K, Raheem O, Ketola K, Lin S, Kast J, Haapasalo H, Hahn WC, Westermarck J (2009) PME-1 protects extracellular signal-regulated kinase pathway activity from protein phosphatase $2 \mathrm{~A}$-mediated inactivation in human malignant glioma. Cancer Res 69:2870-2877. CrossRef Medline

Risner ME, Saunders AM, Altman JF, Ormandy GC, Craft S, Foley IM, Zvartau-Hind ME, Hosford DA, Roses AD (2006) Efficacy of rosiglitazone in a genetically defined population with mild-to-moderate Alzheimer's disease. Pharmacogenomics J 6:246-254. Medline

Rodriguez-Rivera J, Denner L, Dineley KT (2011) Rosiglitazone reversal of Tg2576 cognitive deficits is independent of peripheral gluco-regulatory status. Behav Brain Res 216:255-261. CrossRef Medline

Rosa AO, Egea J, Martínez A, García AG, López MG (2008) Neuroprotective effect of the new thiadiazolidinone NP00111 against oxygen-glucose deprivation in rat hippocampal slices: implication of ERK1/2 and PPARgamma receptors. Exp Neurol 212:93-99. CrossRef Medline

Ryan KK, Li B, Grayson BE, Matter EK, Woods SC, Seeley RJ (2011) A role for central nervous system PPAR-gamma in the regulation of energy balance. Nat Med 17:623-626. CrossRef Medline

Rytinki MM, Palvimo JJ (2009) SUMOylation attenuates the function of PGC-1alpha. J Biol Chem 284:26184-26193. CrossRef Medline
Sadygov RG, Zhao Y, Haidacher SJ, Starkey JM, Tilton RG, Denner L (2010) Using power spectrum analysis to evaluate (18)O-water labeling data acquired from low resolution mass spectrometers. J Proteome Res 9:4306-4312. CrossRef Medline

Scacchi R, Pinto A, Gambina G, Rosano A, Corbo RM (2007) The peroxisome proliferator-activated receptor gamma (PPAR-gamma2) Pro12Ala polymorphism is associated with higher risk for Alzheimer's disease in octogenarians. Brain Res 1139:1-5. CrossRef Medline

Schroeter H, Bahia P, Spencer JP, Sheppard O, Rattray M, Cadenas E, RiceEvans C, Williams RJ (2007) (-)Epicatechin stimulates ERK-dependent cyclic AMP response element activity and up-regulates GluR2 in cortical neurons. J Neurochem 101:1596-1606. CrossRef Medline

Selcher JC, Nekrasova T, Paylor R, Landreth GE, Sweatt JD (2001) Mice lacking the ERK1 isoform of MAP kinase are unimpaired in emotional learning. Learn Mem 8:11-19. CrossRef Medline

Shao D, Rangwala SM, Bailey ST, Krakow SL, Reginato MJ, Lazar MA (1998) Interdomain communication regulating ligand binding by PPARgamma. Nature 396:377-380. CrossRef Medline

Starkey JM, Zhao Y, Sadygov RG, Haidacher SJ, Lejeune WS, Dey N, Luxon BA, Kane MA, Napoli JL, Denner L, Tilton RG (2010) Altered retinoic acid metabolism in diabetic mouse kidney identified by $\mathrm{O}$ isotopic labeling and 2D mass spectrometry. PLoS One 5:e11095. CrossRef Medline

Strum JC, Shehee R, Virley D, Richardson J, Mattie M, Selley P, Ghosh S, Nock C, Saunders A, Roses A (2007) Rosiglitazone induces mitochondrial biogenesis in mouse brain. J Alzheimers Dis 11:45-51. Medline

Sultana R, Boyd-Kimball D, Cai J, Pierce WM, Klein JB, Merchant M, Butterfield DA (2007) Proteomics analysis of the Alzheimer's disease hippocampal proteome. J Alzheimers Dis 11:153-164. Medline

Swatton JE, Sellers LA, Faull RL, Holland A, Iritani S, Bahn S (2004) Increased MAP kinase activity in Alzheimer's and Down syndrome but not in schizophrenia human brain. Eur J Neurosci 19:2711-2719. CrossRef Medline

Sweatt JD (2004) Mitogen-activated protein kinases in synaptic plasticity and memory. Curr Opin Neurobiol 14:311-317. CrossRef Medline

Vidović D, Busby SA, Griffin PR, Schürer SC (2011) A combined ligandand structure-based virtual screening protocol identifies submicromolar PPARgamma partial agonists. ChemMedChem 6:94-103. CrossRef Medline

von Knethen A, Tzieply N, Jennewein C, Brüne B (2010) Casein-kinase-IIdependent phosphorylation of PPARgamma provokes CRM1-mediated shuttling of PPARgamma from the nucleus to the cytosol. J Cell Sci 123: 192-201. CrossRef Medline

Watson GS, Cholerton BA, Reger MA, Baker LD, Plymate SR, Asthana S, Fishel MA, Kulstad JJ, Green PS, Cook DG, Kahn SE, Keeling ML, Craft S (2005) Preserved cognition in patients with early Alzheimer disease and amnestic mild cognitive impairment during treatment with rosiglitazone: a preliminary study. Am J Geriatr Psychiatry 13:950-958. CrossRef Medline

Willson TM, Cobb JE, Cowan DJ, Wiethe RW, Correa ID, Prakash SR, Beck KD, Moore LB, Kliewer SA, Lehmann JM (1996) The structure-activity relationship between peroxisome proliferator-activated receptor gamma agonism and the antihyperglycemic activity of thiazolidinediones. J Med Chem 39:665-668. CrossRef Medline

Wu Z, Xie Y, Bucher NL, Farmer SR (1995) Conditional ectopic expression of C/EBP beta in NIH-3T3 cells induces PPAR gamma and stimulates adipogenesis. Genes Dev 9:2350-2363. CrossRef Medline

Wu Z, Rosen ED, Brun R, Hauser S, Adelmant G, Troy AE, McKeon C, Darlington GJ, Spiegelman BM (1999) Cross-regulation of C/EBP alpha and PPAR gamma controls the transcriptional pathway of adipogenesis and insulin sensitivity. Mol Cell 3:151-158. CrossRef Medline

Zhang HL, Gu ZL, Savitz SI, Han F, Fukunaga K, Qin ZH (2008) Neuroprotective effects of prostaglandin $A(1)$ in rat models of permanent focal cerebral ischemia are associated with nuclear factor-kappaB inhibition and peroxisome proliferator-activated receptor-gamma up-regulation. J Neurosci Res 86:1132-1141. CrossRef Medline

Zhang HL, Xu M, Wei C, Qin AP, Liu CF, Hong LZ, Zhao XY, Liu J, Qin ZH (2011) Neuroprotective effects of pioglitazone in a rat model of permanent focal cerebral ischemia are associated with peroxisome proliferator-activated receptor gamma-mediated suppression of nuclear factor-kappaB signaling pathway. Neuroscience 176:381-395. CrossRef Medline

Zhu Y, Qi C, Korenberg JR, Chen XN, Noya D, Rao MS, Reddy JK (1995) 
Structural organization of mouse peroxisome proliferator-activated receptor gamma (mPPAR gamma) gene: alternative promoter use and dif- ferent splicing yield two mPPAR gamma isoforms. Proc Natl Acad Sci U S A 92:7921-7925. CrossRef Medline 